\title{
ВЫЯВЛЕНИЕ ОБЛАСТЕЙ ПРИРОДНОГО И ТЕХНОГЕННОГО РАЗУПЛОТНЕНИЯ ПОДРАБОТАННОЙ ТОЛЩИ ПО ГРАВИМЕТРИЧЕСКИМ ДАННЫМ
}

\author{
С.Г. Бычков \\ Горный институт УрО РАН, г. Пермь
}

\begin{abstract}
Аннотация. Показано значение гравиразведки для изучения и прогнозирования негативных инженерно-геологических явлений с целью повышения безопасности горных работ при эксплуатации месторождений солей. Установлено, что все провалы земной поверхности приурочены к локальным отрицательным аномалиям силы тяжести, которые характеризуют природные разуплотненные зоны. Представлены результаты гравиметрического мониторинга изменения плотностного состояния горных пород.
\end{abstract}

Ключевые слова: гравиразведка, аномалии силы тяжести, мониторинг, безопасности горных работ.

\section{Введение}

Длительные техногенные нагрузки, связанные с эксплуатацией месторождений полезных ископаемых, являются мощным воздействием на природную среду. Результатом этих воздействий могут быть масштабные изменения, ведущие к катастрофическим последствиям, - просадкам и провалам земной поверхности, угрожающим жизнедеятельности и приносящим значительные экономические потери [1]. Для изучения и прогнозирования негативных инженерно-геологических явлений широко используют геофизические методы [2], немаловажную роль в комплексе которых играют гравиметрические исследования $[3,6,8,10]$. Актуальность задачи выявления техногенного воздействия на геологическую среду обусловлена катастрофическими авариями, связанными с затоплением рудников Верхнекамского месторождения калийных солей. Учитывая высокую практическую значимость месторождения для развития калийной промышленности России, изучению его геологического строения уделяется большое внимание.

Природные зоны разуплотненных пород отчетливо фиксируются в гравитационном поле [8]. Повторные гравиметрические наблюдения позволяют получить динамические аномалии поля силы тяжести, которые независимы от «стационарных» плотностных неоднородностей, обусловленных геологическим строением исследуемого участка, и отражают только процесс воздействия на геологическую среду эксплуатацией месторождений $[3,5]$. Совместная интерпретация локальных аномалий силы тяжести и динамических аномалий с использованием имеющейся геологической информации, с данными об оседаниях земной поверхности и с учетом геометрии горных выработок позволяет построить достоверные трехмерные модели водозащитной толщи, включающей в себя изменение плотности во времени, тем самым определить генезис зон разуплотнения и классифицировать аномалии по степени их опасности для ведения горных работ и жизнедеятельности $[4,9]$.

\section{Гравиметрические работы на аварийных участках Верхнекамского месторождения калийных солей}

В 2006 г. на Верхнекамском месторождении калийных солей проникновение подземных вод в шахты Первого Березниковского рудника, расположенного под промышленной зоной и жилыми кварталами г. Березники, привело к его затоплению и последующим провалам земной поверхности. В районе провалов в разное время проведены детальные гравиметрические съемки с целью оконтуривания и изучения опасных зон, определения глубины распространения разуплотненных пород, а также выявления потенциально опасных участков на прилегающих территориях $[6,7,8]$. 
На рис. 1 приведено сводное гравитационное поле, построенное по данным съемок, проведенных на разных участках в районе провалов земной поверхности. Интерпретация гравиметрических данных показала, что источники отрицательных аномалий силы тяжести находятся в водозащитной толще месторождения солей на глубинах 20-40 м. Как видно из рис. 1, все провалы земной поверхности находятся в пределах отрицательных локальных аномалий силы тяжести, которые характеризуют природные разуплотненные зоны.

С целью изучения изменения плотностного состояния массива горных пород во времени и в пространстве в северной части территории на участках I и II выполнены мониторинговые гравиметрические наблюдения.

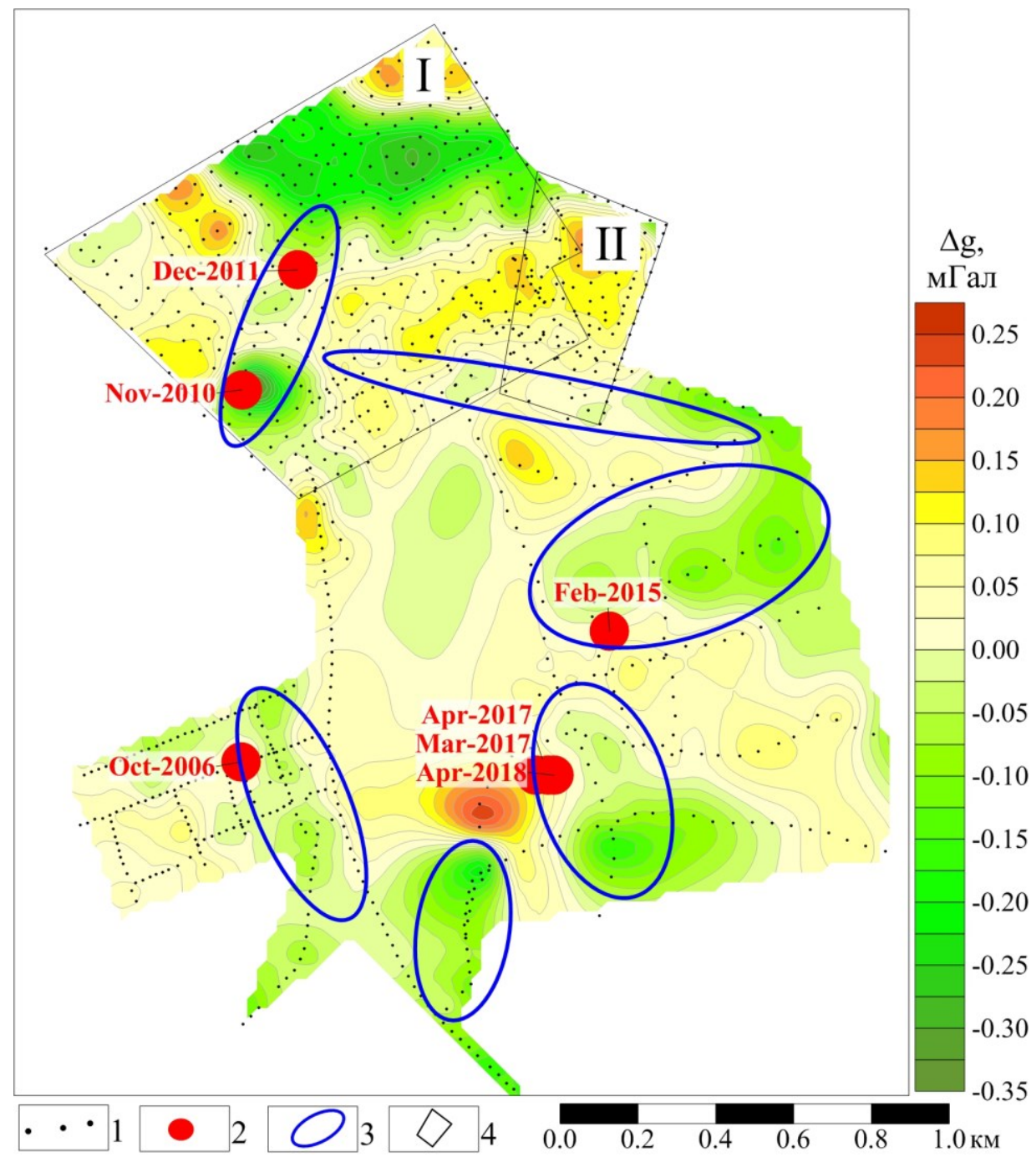

Рис. 1. Гравитационное поле в районе провалов земной поверхности: 1 - пункты гравиметрических наблюдений;

2 - провалы земной поверхности и дата провала;

3 - контуры локальных отрицательных аномалий силы тяжести 4 - участки повторной гравиметрической съемки

\section{Гравиметрический мониторинг}

На участке I (см. рис. 1) гравиметрические наблюдения проведены в ноябре 2010 г. и феврале 2011 г. на всей площади и в сентябре 2011 г. в центральной части. В разные периоды 2016 - 2019 гг. съемка выполнялась на востоке площади (участок II). Карта изменения значений силы тяжести (динамические аномалии) приведена на рис. 2. 
Первый цикл гравиметрических съемок в конце 2010 г. и начале 2011 г. был проведен после провала земной поверхности, контур которого обозначен цифрой I на рис. 2. Динамические аномалии силы тяжести были выявлены только вблизи этого провала, что свидетельствовало о продолжении процесса разуплотнения пород и расширении провала [8]. Результаты интерпретации динамической аномалии показали, что зона разуплотнения расположена на глубинах 40-70 м и приурочена к водозащитной надсоляной толще.

В сентябре 2011 г. в зоне повышенных оседаний земной поверхности к северу от провала I проведены повторные гравиметрические измерения, по результатам которых выявлена динамическая аномалия силы тяжести, свидетельствующая о процессе разуплотнения пород, начавшемся после февраля 2011 г., поскольку в первом цикле наблюдений динамической аномалии здесь не фиксировалось. В результате интерпретации как самого гравитационного поля, так и его изменения во времени, оконтурена зона разуплотненных пород и определены возможные источники данной аномалии [3]. В пределах зоны отрицательных локальных аномалий гравитационного поля северного простирания и динамической аномалии силы тяжести, выявленной по съемке в сентябре 2011 г., через три месяца в декабре 2011 г. сформировался еще один провал земной поверхности (обозначен цифрой II на рис. 2). Дальнейшее развитие природной зоны разуплотненных пород, которая отражается отрицательной локальной аномалией силы тяжести (рис. 1), привело к объединению провалов I и II и образованию здесь в 2014 г. техногенного озера.

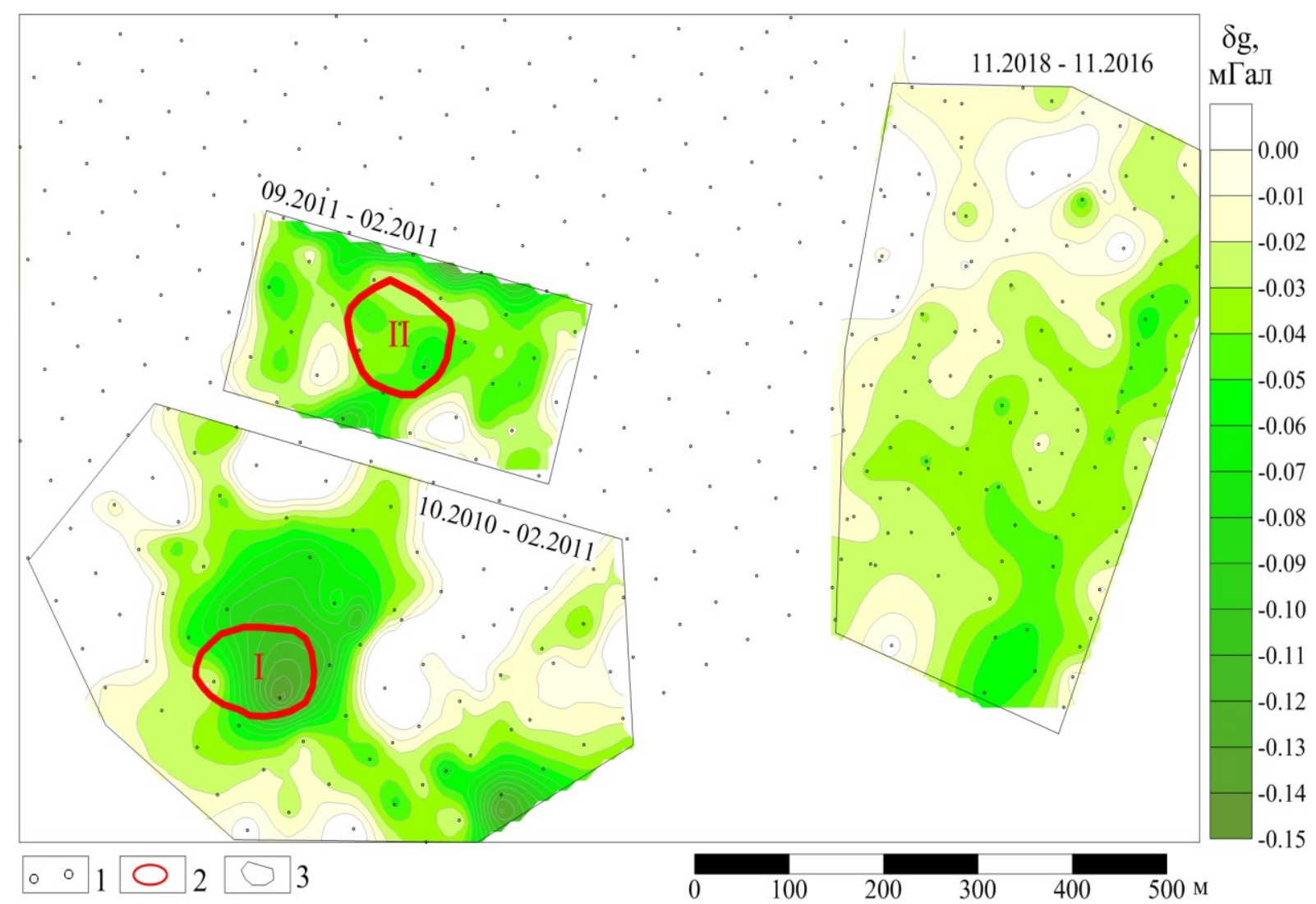

Рис. 2. Динамические аномалии силы тяжести в разные периоды времени: 1 - пункты гравиметрических наблюдений;

2 - провалы земной поверхности (I - 11.2010 г. и II - 12.2011 г.);

3 - участки повторной гравиметрической съемки (датами указан период динамической аномалии) 
Пространственное совпадение динамической и локальной отрицательной аномалии силы тяжести в районе провалов I и II можно интерпретировать как существование природных зон разуплотнения пород, к которым приурочены техногенные карстовые процессы, приводящие к провалам земной поверхности.

\section{Выводы}

Гравиметрические исследования на Верхнекамском месторождении вносят определенный вклад в изучение плотностной неоднородности верхней части разреза, в обеспечение безопасности и жизнедеятельности. Изменения плотности пород в горном массиве, происходящие под влиянием горно-геологических условий, отчетливо фиксируются в гравитационном поле. Разрабатываемая технология проведения и интерпретации мониторинговых гравиметрических наблюдений позволяет перейти на новый качественный уровень получения информации о распределении и развитии во времени плотностных неоднородностей геологического разреза, что существенно повышает безопасность проведения горных работ. Гравиразведка позволяет на предварительном этапе уточнить геолого-тектоническую обстановку в пределах шахтных полей, выделить зоны повышенного риска.

\section{Работа выполнена при поддержке РФФИ (проект № 19-45-590011р_а).}

\section{БИБЛИОГРАФИЧЕСКИЙ СПИСОК}

1. Барях А.А., Красноштейн А.Е., Санфиров И.А. Горнотехнические аварии: затопление первого Березниковского калийного рудника // Вестн. Перм. науч. центра. - 2009. - №2. - С. 40-49.

2. Барях А.А., Санфиров И.А., Дягилев Р.А. Мониторинг последствий затопления калийного рудника // Горный журнал. - 2013 - № 6. - С. 34-39.

3. Бычков С.Г., Мичурин А.В., Симанов А.А. Гравиметрический мониторинг рудников Верхнекамского месторождения калийных солей // Геофизика. - 2017. - № 5. - С. 10-16.

4. Бычков С.Г., Мичурин А.В., Симанов А.А. Интерпретация результатов гравиметрического мониторинга на аварийных участках рудников Верхнекамского месторождения калийных солей // Вопросы теории и практики геологической интерпретации гравитационных, магнитных и электрических полей: сб. науч. тр. Вып. 1 (46) / ГИ УрО РАН [и др.]. - Пермь, 2019. - С. 59-63.

5. Бычков С.Г., Мичурин А.В., Симанов А.А., Хохлова В.В. Выявление техногенных изменений в водозащитной толще месторождения калийных солей по мониторинговым гравиметрическим наблюдениям // Вопросы теории и практики геологической интерпретации геофизических полей: материалы 47-й сес. Междунар. семинара Д.Г. Успенского - В.Н. Страхова / Воронеж. Гос. ун-т [и др.]. - Воронеж, 2020. - С. 49-51.

6. Бычков С.Г., Мичурин А.В., Симанов А.А., Хохлова В.В. Гравиметрические исследования состояния геосреды в районах интенсивного освоения недр // Горный журнал. - 2019. - № 12. - С. 90-94. DOI:10.17580/gzh.2019.12.19.

7. Бычков С.Г., Простолупов Г.В., Щербинина Г.П. Выявление техногенных изменений в подработанном массиве по гравиметрическим данным на Верхнекамском месторождении солей // Геофизика. 2019. - № 5. - С. 43-49.

8. Щербинина Г.П., Простолупов Г.В., Бычков С.Г. Гравиметрические исследования техногенных воздействий на геологическую среду // Вопросы теории и практики геологической интерпретации гравитационных, магнитных и электрических полей: материалы 40-й сес. Междунар. семинара им. Д.Г. Успенского / ИФЗ РАН [и др.]. - М., 2013. - С. 392-395.

9. Bychkov S., Michurin A., Simanov A. Interpretation of results gravity monitoring of karst processes // Innovations in Geosciences - Time for Breakthrough: 8th International Conference \& Exibition, 9-12 april 2018, Saint Petersburg. - St.-Petersburg, 2018. - Код 137602, номер статьи 44417.

10. Bychkov S.G., Michurin A.V., Simanov A.A. Gravimetric monitoring of technogenic impact on geological environment // Engineering and mining Geophysics 2018: 14th Conference \& Exhibition, 23-27 april 2018. - Almaty, 2018. - code 137600. - DOI:10.3997/2214-4609.201800459. 